\title{
MOLECULAR EVENTS IN THE WHARTON'S JELLY AND BLOOD VESSELS OF HUMAN UMBILICAL CORD
}

\author{
Elga Sidhom ${ }^{1}$, Māra Pilmane ${ }^{1}$, Ilze Kreicberga ${ }^{2}$ \\ ${ }^{1}$ Institute of Anatomy and Anthropology, Riga Stradiňš University, Latvia \\ ${ }^{2}$ Department of Obstetrics and Gynaecology, Riga Stradinš University, Latvia
}

\begin{abstract}
The umbilical cord is seen as the main junction between the developing embryo or fetus and placenta. We studied the antimicrobial response, the presence of undifferentiated cells and TGF- $\alpha$, as well as tissue degeneration and compensatory remodelling processes in the cells of human umbilical cord.

Seven umbilical cord tissue samples obtained during premature and full term births were stained with hematoxylin and eosin and by immunohistochemistry for human beta defensin 2 (hBD-2), hematopoietic progenitor cell antigen CD34, matrix metalloproteinase 2 (MMP-2), the tissue inhibitor of matrix metalloproteinase 2 (TIMP-2), nestin and transforming growth factor alpha (TGF- $\alpha$ ). The intensity of staining was graded semiquantitatively.

Antimicrobial response was more prominent in the Wharton's jelly - we found numerous hBD-2-containing cells, while hBD-2 positive cells in the walls of arteries and vein varied from moderate to abundance. Numerous cells in the Wharton's jelly contained CD34, while in the walls of blood vessels few to moderate stained positive for CD34. MMP-2, TIMP-2 and nestin positive cells were found in all the tissue samples and varied from numerous in the walls of blood vessels to abundance in the Wharton's jelly and the inflammation region. The abundance of TGF- $\alpha$-containing cells was found in Wharton's jelly and moderate to numerous cells of blood vessels contained TGF- $\alpha$.

Conclusions: The human umbilical cord possesses antimicrobial activity and shows the presence of undifferentiated cells. The striking distribution and the expression of MMP-2, TIMP-2 and nestin suggest their role in the very effective and extensive tissue degeneration and compensatory remodelling processes. TGF- $\alpha$ seems to be an important growth factor for extra-embryonic tissue development.
\end{abstract}

Keywords: umbilical cord; Wharton's jelly; mesenchymal stem cells; immunohistochemistry; tissue remodelling 


\section{INTRODUCTION}

Umbilical cord is seen as the main junction between the developing embryo or fetus and placenta. At the same time the human umbilical cord tissue should also be considered as a possible extensive source of mesenchymal stem cells. The mesenchymal stem cells derived from the Wharton's jelly of the human umbilical cord have been isolated with the help of the enzymatic digestion method and have shown positive CD73, CD90 and CD105 cell surface markers, while CD14, CD34, DC45, CD79, HLA-DR are supposedly negative. Human mesenchymal stem cells as non-hematopoietic and multipotent stem cells have the ability to differentiate into mesodermal lineage (osteocytes, adipocytes, and chondrocytes), ectodermal (neurocytes) and endodermal lineages (hepatocytes) [33]. Mesenchymal stem cells have been found in the various compartments of the human umbilical cord, but the cells localized perivascularly and especially in the Wharton's jelly so far show the biggest possible clinical utility. Mesenchymal stem cells isolated from the Wharton's jelly can be generated in large numbers with minimal culture avoiding changes in phenotype, have the least non-stem cell contaminants, their derivation is quick and easy to standardize, they are rich in stemness characteristics and have a high differentiation potential [31].

Mesenchymal stem cells derived from the Wharton's jelly of the human umbilical cord have a good accessibility and high expansion potential. Therefore, mesenchymal stem cells found in the human umbilical cord could be considered a very good alternative to the bone marrow-derived mesenchymal stem cells and could possibly trans-differentiate into neurons or glial cells under special circumstances [37]. It is suggested that human mesenchymal stem cells could have antifibrotic properties with paracrine signalling as one of the main underlying mechanisms behind their therapeutic effects. This therapeutical property might possibly be valuable when treating keloids and renal scarring $[3,13]$. Similarly experimental studies have shown the ability of the Wharton's jelly-derived mesenchymal stem cells to differentiate into adipocytelike cells with high chemokine secreting properties [2]. The Wharton's jellyderived mesenchymal stem cells closely interact with peripheral blood mononuclear cells alternating tissue homeostasis, cell death, production of cytokines and chemokines [19]. At the same time it is also shown that in the co-culture model placental cells can provide a proper environment for the induction of human umbilical cord mesenchymal stem cells into primordial germ cells and reach oocyte-like cells in vitro with the expression of oocyte-like markers [4]. 
Defensins as a group of antimicrobial peptides provide the first line of defense in the innate immune response against various pathogens. Their role has been actively discussed in wound healing, angiogenesis, immunomodulation, inflammatory diseases and malignancies [12]. It has been suggested that the increased expression of human beta defensin 2 along with cathelicidin could play an important role in homing non-hematopoietic stem cells to damaged myocardium after myocardial infarction [17]. Similar antimicrobial peptide effect on hematopoietic stem cells was detected in bone marrow during the recovery process after the transplantation of hematopoietic stem progenitor cells [27]. Hematopoietic progenitor cell antigen CD34 is a general marker on progenitor cells in various cell types. The expression of CD34 has been found early in the development in tissues associated with hematopoietic and vascular systems, predominantly in the umbilical cord and bone marrow [29]. Cells positive for CD34 are possibly good agents for clinical cell transplantation and the source that could be explored further in regenerative medicine [28].

Matrix metalloproteinases belong to the family of extracellular proteinases with a role in developmental biology, as well as tumor cell invasion and metastasis. During tissue remodelling and organ development matrix metalloproteinases provide the rearrangement of the extracellular matrix and modulate signalling pathways through proteolytic interaction with multiple substrate molecules [18]. These proteinases are able to effectively take part in such biological events as development, tissue remodelling and homeostasis only together with sufficient expressions of their tissue inhibitors [25]. Nestin is an intermediate filament protein expressed in the early stages of development and has been found to be expressed in neural stem cells, as well as endothelial cells, cancer cells and fibroblasts. It is suggested that nestin could serve as a specific marker for mesenchymal stem cells [34].

Mesenchymal stem cells hold an immunoregulatory capacity and are able to interfere with different pathways of the immune response by direct cell interactions or by secreting soluble factors. Such a possible molecule involved in the immunosuppressive effect of mesenchymal stem cells seems to be a transforming growth factor [10].

The aim of the study was to evaluate the antimicrobial response, the presence of undifferentiated cells and the transforming growth factor alpha, as well as tissue degeneration and compensatory remodelling processes in the human umbilical cord. 


\section{MATERIAL AND METHODS}

In this study we included seven umbilical cord tissue samples obtained during both premature and full term births. The gestational age varied from 28 to 40 weeks. Five newborns were girls, two - boys.

The umbilical cord tissue was fixed in the Stefanini's solution, dehydrated and embedded in paraffin. Four micrometer-thick sections were prepared and stained with hematoxylin and eosin $[15,30]$.

hBD-2 (Cat No AF2758, Lot No VJU01, obtained from goat, dilution 1:100, R\&D Systems, Germany), CD34 (code sc-19621, obtained from mouse, dilution 1:100, Santa Cruz Biotechnology, Inc., USA), MMP-2 (Cat No AF902, Lot No DUB03, obtained from goat, dilution 1:100, R\&D Systems, Germany), TIMP-2 (code sc-21735, obtained from mouse, dilution 1:50, Santa Cruz Biotechnology, Inc., USA), nestin (code ab22035, obtained from mouse, dilution 1:250, Abcam, UK) and TGF- $\alpha$ (code ab9578, obtained from mouse, dilution 1:100, Abcam, UK) primary antibodies were used in biotin-streptavidin immunohistochemistry (IMH) [16].

Umbilical cord tissues were deparaffinized, washed in alcohol and water, wash buffer (Tris-buffered saline) and microwaved in boiling EDTA buffer, afterwards again washed twice in wash buffer. Tissue samples were blocked with normal blocking sera for 20 minutes to decrease background staining. All the samples were stained with primary antibodies for 1 hour, washed in wash buffer and then stained for 30 minutes with LSAB+LINK with biotinrelated secondary antibodies (code K1015, DakoCytomation, Denmark) and washed again in wash buffer. We further stained our samples for 25 minutes with LSAB+LINK with peroxidase-labeled streptavidin (code K0690, DakoCytomation, Denmark), washed in wash buffer and processed for 10 minutes with DAB substrate-chromogen system (code K3468, DakoCytomation, Denmark) to stain positive structures brown. Samples were then rinsed in running water and counterstained with hematoxylin.

Samples were examined on Leica DC 300F camera, image processing and the analysis was performed on Image Pro Plus 6.0 software (Media Cybernetics, Silver Spring, Maryland, USA).

The intensity of immunostaining was graded semiquantitatively, as follows [26]:

- few positive structures in the visual field were labeled +,

- a moderate number of positive structures in the visual field was labeled ++, 
- numerous positive structures in the visual field were labeled +++,

- and an abundance of positive structures in the visual field was marked ++++.

For statistical analyses we used non-parametric statistics and the Spearman's rank correlation coefficient [9].

\section{RESULTS}

All the tissue samples contained preserved two umbilical arteries and one umbilical vein. In five tissue samples we observed no visual inflammatory or degenerative changes. In two specimens we found extensive distribution of inflammatory cells (macrophages and lymphocytes) both in the Wharton's jelly and in the walls of arteries.

Antimicrobial response was more prominent in the Wharton's jelly - we found numerous $(+++)$ hBD-2-containing cells, while hBD-2 positive cells in the walls of arteries and vein varied from a moderate number $(++)$ to abundance $(++++)$. We have to note that the distribution of hBD-2 was selective as in some of our tissue samples only one of two arteries demonstrated the presence of the studied factor. The abundance of hBD-2-containing cells was found in the areas of well-defined inflammation (Fig. 1) (Table 1).

The presence of CD34 was found in endothelium of both umbilical arteries and veins, as well as in extra-embryonic mesoderm. Numerous $(+++)$ cells in the Wharton's jelly contained CD34, while in the walls of blood vessels few $(+)$ to a moderate number $(++)$ of cells stained positive for CD34 (Fig. 2).

MMP-2, TIMP-2 and nestin positive cells were found in all the tissue samples and varied from numerous $(+++)$ in the walls of blood vessels to abundance $(++++)$ in the Wharton's jelly and inflammation region (Fig. 3-5).

The abundance $(++++)$ of TGF- $\alpha$-containing cells was found in the Wharton's jelly and also moderate $(++)$ to numerous $(+++)$ cells of blood vessels contained TGF- $\alpha$ (Fig. 6).

We found statistically significant strong positive correlation between CD34 and MMP-2 expression (the Spearman's rank correlation coefficient was 0.881 $(P$ value $=0.008)$ ). No statistically significant correlations were found between the remaining studied factors. 
Table 1. Relative amount of hBD-2, CD34, MMP-2, TIMP-2, nestin and TGF-a positive structures in umbilical cord tissue

\begin{tabular}{|c|c|c|c|c|c|c|c|c|}
\hline $\begin{array}{l}\text { Tissue } \\
\text { sample }\end{array}$ & Clinical data & $\begin{array}{c}\text { Gestational } \\
\text { weeks and } \\
\text { gender }\end{array}$ & hBD-2 & CD34 & $\begin{array}{l}\text { MMP- } \\
2\end{array}$ & $\begin{array}{c}\text { TIMP- } \\
2\end{array}$ & Nestin & TGF-a \\
\hline No. 1 & $\begin{array}{l}\text { Premature } \\
\text { spontaneous } \\
\text { labour }\end{array}$ & $28, F$ & +++ & +++ & ++++ & ++++ & ++++ & +++ \\
\hline No. 2 & $\begin{array}{l}2^{\text {nd }} \text { pregnancy, } \\
\text { premature } \\
\text { spontaneous } \\
\text { labour }\end{array}$ & $30, M$ & ++++ & +++ & ++++ & ++++ & +++ & +++ \\
\hline No. 3 & $\begin{array}{l}2^{\text {nd }} \text { pregnancy, } \\
\text { premature } \\
\text { operative labour }\end{array}$ & $31, F$ & +++ & ++ & +++ & +++ & ++++ & +++ \\
\hline No. 4 & $\begin{array}{l}2^{\text {nd }} \text { pregnancy, } \\
1^{\text {st }} \text { labour, } \\
\text { premature } \\
\text { operative labour }\end{array}$ & $34, F$ & ++++ & ++++ & ++++ & +++ & ++++ & ++++ \\
\hline No. 5 & $\begin{array}{l}2^{\text {nd }} \text { pregnancy, } \\
1^{\text {st }} \text { labour, } \\
\text { operative } \\
\text { labour, distress }\end{array}$ & $39, F$ & ++++ & +++ & ++++ & ++++ & +++ & ++++ \\
\hline No. 6 & $\begin{array}{l}1^{\text {st }} \text { pregnancy, } \\
\text { spontaneous } \\
\text { labour, maternal } \\
\text { distress }\end{array}$ & $40, M$ & +++ & +++ & ++++ & +++ & ++++ & +++ \\
\hline No. 7 & $\begin{array}{l}3^{\text {rd }} \text { pregnancy, } \\
1^{\text {st }} \text { labour, op- } \\
\text { erative labour, } \\
\text { acute maternal } \\
\text { distress, intra- } \\
\text { natal death of } \\
\text { fetus }\end{array}$ & $40, F$ & +++ & ++ & +++ & ++++ & ++++ & ++++ \\
\hline Mean & & & +++ & +++ & ++++ & ++++ & ++++ & ++++ \\
\hline
\end{tabular}

Abbreviations: hBD-2 - human beta defensin 2; CD34 - hematopoietic progenitor cell antigen CD34; MMP-2 - matrix metalloproteinase 2; TIMP-2 - tissue inhibitor of matrix metalloproteinase 2; TGF- $\mathrm{a}$ - transforming growth factor alpha; $\mathrm{M}$ - male; $\mathrm{F}$ - female; + few positive structures in the visual field; ++ a moderate number of positive structures in the visual field; +++ numerous positive structures in the visual field; ++++ an abundance of positive structures in the visual field. 


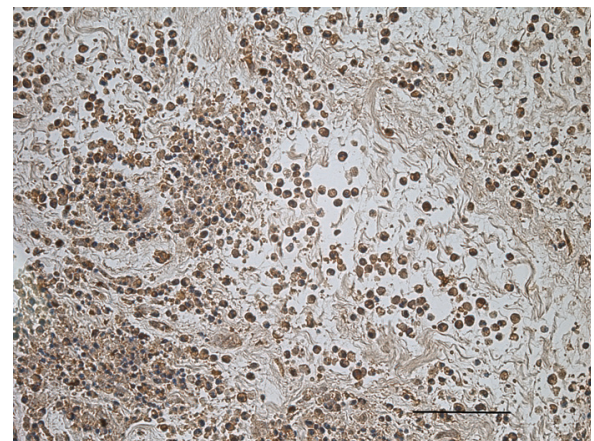

Figure 1. Prominent antimicrobial response in the Wharton's jelly abundance of hBD-2-containing inflammatory cells. hBD-2 IMH, $\times 250$, scale bar: $5.8 \mu \mathrm{m}$.

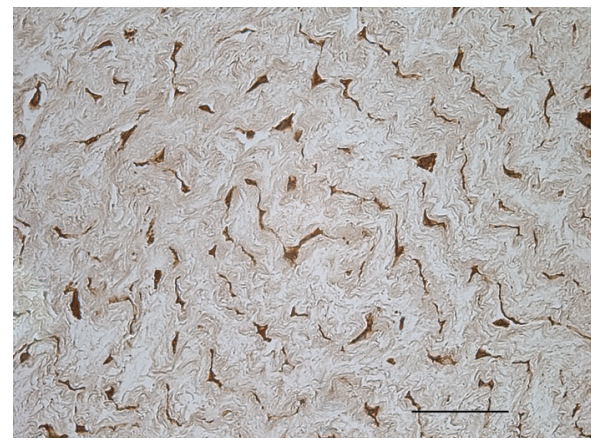

Figure 3. Abundance of MMP-2 positive cells in the Wharton's jelly. MMP-2 IMH, $\times 250$, scale bar: $5.8 \mu \mathrm{m}$.

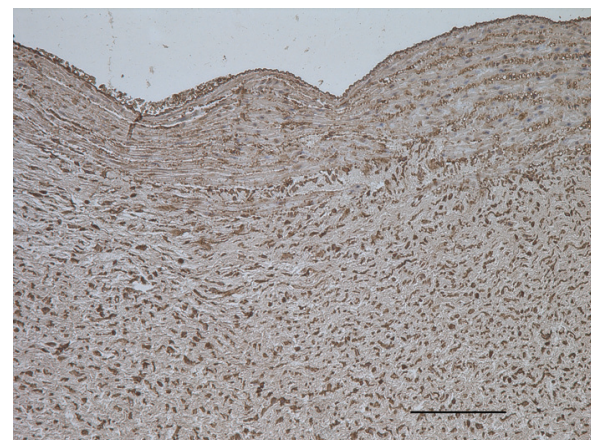

Figure 5. Numerous nestin-containing cells in umbilical blood vessels. Nestin IMH, $\times 100$, scale bar: $14.5 \mu \mathrm{m}$.



Figure 2. Moderate number of cells stained positive for CD34 in walls of blood vessels. CD34 IMH, $\times 250$, scale bar: $5.8 \mu \mathrm{m}$.

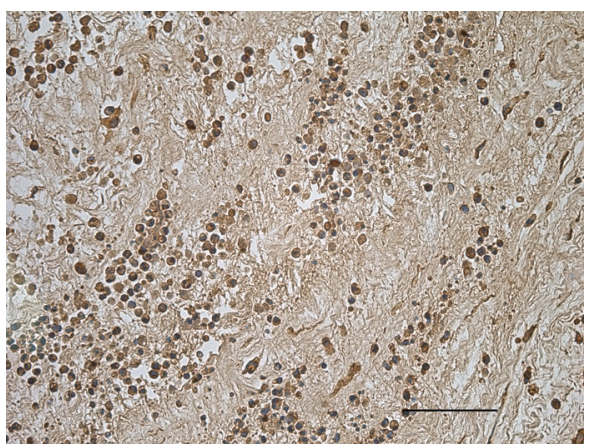

Figure 4. Numerous TIMP-2-containing cells in the Wharton's jelly and especially in the inflammation region. TIMP-2 IMH, $\times 250$, scale bar: $5.8 \mu \mathrm{m}$.

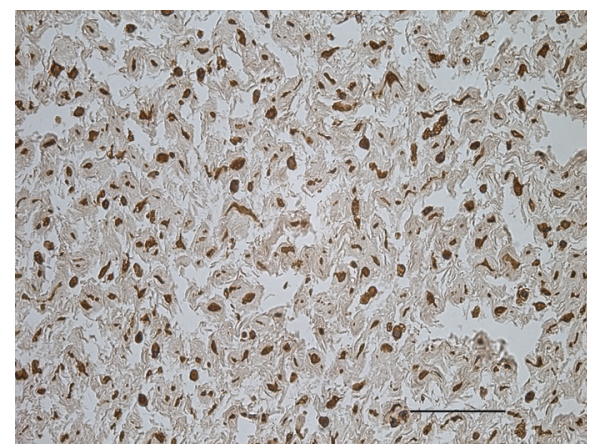

Figure 6. Abundance of TGF-a-containing cells in the Wharton's jelly. TGF-a IMH, $\times 250$, scale bar: $5.8 \mu \mathrm{m}$. 


\section{DISCUSSION}

Various types of human cells express antimicrobial peptides and they act on a broad spectrum of bacterial, fungal and viral agents. The hBD-2 obtained during intratracheal transplantation of human umbilical cord blood-derived mesenchymal stem cells in the experimental mouse model has been shown to primarily down-modulate inflammation and enhance bacterial clearance in Escherichia coli-induced acute lung injury [32]. Another study suggests that the Wharton's jelly-derived mesenchymal stem cells having a low immunogenicity and immunomodulatory effect might be related to direct cell contact and the inhibition of cytokine secretion by human peripheral blood lymphocytes [36]. In our study, we evaluated hBD-2 expression in the umbilical cord tissue and found that it was expressed in all the samples with the highest expression in inflammatory areas. Also, the umbilical cord tissue samples obtained during premature spontaneous or operative labours presented more obvious hBD-2 expression. While we did not find direct correlations with the internal and the external factors affecting placenta, possibly, the factors inducing premature labour or surgical intervention and associated inflammatory reaction are the direct regulators of the antimicrobial response.

CD34 together with nestin in the Wharton's jelly-derived mesenchymal stem cells are upregulated under hypoxia. Probably in in vitro culturing these cells might adopt mesodermal growth kinetics [24]. At the same time another study reports inability to isolate CD34 from the Wharton's jelly mucoid connective tissue or fibroblast-like cells using the flow cytometric analysis. Not only CD34 was absent, also hematopoietic lineage marker CD45 was not found [35]. The absence of hematopoietic and endothelial markers in the Wharton's jellyderived mesenchymal stem cells together with the predominant expression of surface antigen markers CD29, CD44, CD73, CD90, CD105 and CD166 using flow cytometry, immunofluorescence and qRT-PCR analysis has also been reported [1]. We found a clear upregulation of CD34 in our samples; previously the available data on CD34 finding has been controversial. One potential explanation is that general belief on CD34 negative mesenchymal stem cells is based on the studies using cell cultures while tissue-resident mesenchymal stem cells can possibly be and are CD34 positive. Thus, the negative finding of CD34 can be a direct result of cell culturing [21]. CD34 positive cells have also been associated with the vascular stem cells that reside within the wall of the blood vessel and can differentiate into all the cell types that constitute a fully functional blood vessel, including smooth muscle cells [22]. This suggestion 
explains the presence of CD34-containing cells found in the walls of blood vessels in our tissue samples.

We observed clear upregulation of MMP-2, TIMP-2 and nestin in our tissue samples. With the help of RT-PCR it is reported that the treatment with cerebrospinal fluid promotes the expression of nestin [14]. Meanwhile, the Wharton's jelly-derived mesenchymal stem cells can rapidly lose their therapeutic properties due to oxidative stress [8]. Without any targeted environmental changes nestin together with other neural progenitor cell markers and mature neural markers has been found in the Wharton's jelly-derived mesenchymal stem cells of umbilical cords from preterm and term births [23]. The ability to express nestin might result in mesenchymal cell differentiation into motor neuron-like cells and this property could be explored when targeting the therapy of neurodegenerative diseases [5]. Our study shows that nestin expression is prominent and independent of gestational age. MMP- 2 and other proteases involved in the degradation of the extracellular matrix have been found upregulated in umbilical cord blood-derived and the Wharton's jellyderived mesenchymal stem cells. Their upregulation might be a potential path in exploring scarless wound healing although up to date only the limited data obtained from experimental model is available [11]. We found statistically significant strong positive correlation between CD34 and MMP- 2 which might show the linkage between the hematopoietic and degenerative properties of the cells originating from the umbilical cord. Concomitant increase in the expression of MMP-2 and TIMP-2 has been reported in vitro in human umbilical vein endothelial cells after hypoxia [7]. The prominent presence of MMP-2, TIMP-2 and nestin suggest their role and overall cells derived from the umbilical cord as an important source for tissue degeneration and compensatory remodelling processes.

We found TGF- $\alpha$ both in the Wharton's jelly and the walls of blood vessels which is consistent with the current understanding of the role of TGF- $\alpha$. Several studies have detected increased levels of TGF- $\alpha$ together with other cytokines in the mesenchymal stem cells derived from the umbilical cord in comparison with the cells derived from bone marrow suggesting their immunosuppressive properties $[6,20]$. TGF- $\alpha$ seemingly is an important growth factor for extraembryonic tissue development. Our study was limited to TGF- $\alpha$, but the overall immunosuppressive effect of human mesenchymal stem cells could be further explored in the treatment of various autoimmune diseases.

Our data confirms that the cells derived from the human umbilical cord provide the antimicrobial response; MMP-2, TIMP-2 and nestin are important 
factors in providing the balance between degeneration and tissue remodelling; TGF- $\alpha$ could be targeted for its immunosuppressive properties. While the study is limited to small tissue sample number, it gives essential insight into the properties and molecular events of cells found in the human umbilical cord.

We conclude that the human umbilical cord possesses antimicrobial activity and shows the presence of undifferentiated cells. The striking distribution and the expression of MMP-2, TIMP-2 and nestin suggest their role in the very effective and extensive tissue degeneration and compensatory remodelling processes. TGF- $a$ seems to be an important growth factor for extra-embryonic tissue development.

\section{REFERENCES}

1. Ali H., Al-Yatama M. K., Abu-Farha M., Behbehani K., Al Madhoun A. (2015). Multi-Lineage Differentiation of Human Umbilical Cord Wharton's Jelly Mesenchymal Stromal Cells Mediates Changes in the Expression Profile of Stemness Markers. PLoS One, 10, e0122465. https://doi.org/10.1371/journal.pone.0122465

2. Amable P.R., Teixeira M.V., Carias R.B., Granjeiro J.M., Borojevic R. (2014). Gene expression and protein secretion during human mesenchymal cell differentiation into adipogenic cells. BMC Cell Biol, 15, 46. https://doi.org/10.1186/s12860-014-0046-0

3. Arno A.I., Amini-Nik S., Blit P.H., Al-Shehab M., Belo C., Herer E., Jeschke M.G. (2014). Effect of human Wharton's jelly mesenchymal stem cell paracrine signaling on keloid fibroblasts. Stem Cells Transl Med, 3, 299-307. https://doi.org/10.5966/sctm.2013-0120

4. Asgari H.R., Akbari M., Abbasi M., Ai J., Korouji M., Aliakbari F., Babatunde K.A., Aval F.S., Joghataei M.T. (2015). Human Wharton's jelly-derived mesenchymal stem cells express oocyte developmental genes during co-culture with placental cells. Iran J Basic Med Sci, 18, 22-29.

5. Bagher Z., Ebrahimi-Barough S., Azami M., Mirzadeh H., Soleimani M., Ai J., Nourani M.R., Joghataei M.T. (2015). Induction of human umbilical Wharton's jelly-derived mesenchymal stem cells toward motor neuron-like cells. In Vitro Cell Dev Biol Anim, 51, 987-994. https://doi.org/10.1007/s11626-015-9921-z

6. Bárcia R.N., Santos J.M., Filipe M., Teixeira M., Martins J.P., Almeida J., et al. (2015). What Makes Umbilical Cord Tissue-Derived Mesenchymal Stromal Cells Superior Immunomodulators When Compared to Bone Marrow Derived Mesenchymal Stromal Cells? Stem Cells Int, 2015, 583984.

https://doi.org/10.1155/2015/583984 
7. Cavdar Z., Oktay G., Egrilmez M.Y., Genc S., Genc K., Altun Z., Islekel H., Guner G. (2010). In vitro reoxygenation following hypoxia increases MMP-2 and TIMP-2 secretion by human umbilical vein endothelial cells. Acta Biochim Pol, 57, 69-73.

8. Choo K.B., Tai L., Hymavathee K.S., Wong C.Y., Nguyen P.N., Huang C.J., Cheong S.K., Kamarul T. (2014). Oxidative stress-induced premature senescence in Wharton's jelly-derived mesenchymal stem cells. Int J Med Sci, 11, 1201-1207. https://doi.org/10.7150/ijms.8356

9. Christensen R. (1996). Analysis of Variance, Design and Regression: Applied Statistical Methods. Chapman \& Hall. London.

10. De Miguel M.P., Fuentes-Julián S., Blázquez-Martínez A., Pascual C.Y., Aller M.A., Arias J., Arnalich-Montiel F. (2012). Immunosuppressive properties of mesenchymal stem cells: advances and applications. Curr Mol Med, 12, 574591. https://doi.org/10.2174/156652412800619950

11. Doi H., Kitajima Y., Luo L., Yan C., Tateishi S., Ono Y., Urata Y., Goto S., Mori R., Masuzaki H., Shimokawa I., Hirano A., Li TS. (2016). Potency of umbilical cord blood- and Wharton's jelly-derived mesenchymal stem cells for scarless wound healing. Sci Rep, 6, 18844. https://doi.org/10.1038/srep18844

12. Donnarumma G., Paoletti I., Fusco A. et al. (2016). $\beta$-Defensins: Work in Progress. Adv Exp Med Biol, 901,59-76. https://doi.org/10.1007/5584_2015_5016

13. Du T., Zou X., Cheng J., Wu S., Zhong L., Ju G., Zhu J., Liu G., Zhu Y., Xia S. (2013). Human Wharton's jelly-derived mesenchymal stromal cells reduce renal fibrosis through induction of native and foreign hepatocyte growth factor synthesis in injured tubular epithelial cells. Stem Cell Res Ther, 4, 59. https://doi.org/10.1186/scrt215

14. Farivar S., Mohamadzade Z., Shiari R., Fahimzad A. (2015). Neural differentiation of human umbilical cord mesenchymal stem cells by cerebrospinal fluid. Iran J Child Neurol, 9, 87-93.

15. Fischer A.H., Jacobson K.A., Rose J., Zeller R. (2008). Hematoxylin and eosin staining of tissue and cell sections. CSH Protoc, 2008, pdb.prot4986. https://doi.org/10.1101/pdb.prot4986

16. Hsu S.M., Raine L., Fanger H. (1981). The use of antiavidin antibody and avidin-biotin peroxidase complex in immunoperoxidase technics. Am J Clin Pathol, 75, 816-821. https://doi.org/10.1093/ajcp/75.6.816

17. Karapetyan A.V., Klyachkin Y.M., Selim S., Sunkara M., Ziada K.M., Cohen D.A., Zuba-Surma E.K., Ratajczak J., Smyth S.S., Ratajczak M.Z., Morris A.J., Abdel-Latif A. (2013). Bioactive lipids and cationic antimicrobial peptides as new potential regulators for trafficking of bone marrow-derived stem cells in patients with acute myocardial infarction. Stem Cells Dev, 22, 1645-1656. https://doi.org/10.1089/scd.2012.0488 
18. Kessenbrock K., Wang C.Y., Werb Z. (2015). Matrix metalloproteinases in stem cell regulation and cancer. Matrix Biol, 44-46, 184-190.

https://doi.org/10.1016/j.matbio.2015.01.022

19. Li D., Han Y., Zhuang Y., Fu J., Liu H., Shi Q., Ju X. (2015). Overexpression of COX-2 but not indoleamine 2,3-dioxygenase-1 enhances the immunosuppressive ability of human umbilical cord-derived mesenchymal stem cells. Int J Mol Med, 35, 1309-1316.

20. Li X., Du W., Ma F. X., Feng X., Bayard F., Han Z.C. (2015). High Concentrations of TNF- $\alpha$ Induce Cell Death during Interactions between Human Umbilical Cord Mesenchymal Stem Cells and Peripheral Blood Mononuclear Cells. PLoS One, 10, e0128647. https://doi.org/10.1371/journal.pone.0128647

21. Lin C.S., Ning H., Lin G., Lue T.F. (2012). Is CD34 truly a negative marker for mesenchymal stromal cells? Cytotherapy, 14, 1159-1163.

https://doi.org/10.3109/14653249.2012.729817

22. Lin C.S., Lue T.F. (2013). Defining vascular stem cells. Stem Cells Dev, 22, 1018-1026. https://doi.org/10.1089/scd.2012.0504

23. Messerli M., Wagner A., Sager R., Mueller M., Baumann M., Surbek D.V., Schoeberlein A. (2013). Stem cells from umbilical cord Wharton's jelly from preterm birth have neuroglial differentiation potential. Reprod Sci, 20, 1455-1464. https://doi.org/10.1177/1933719113488443

24. Nekanti U., Dastidar S., Venugopal P., Totey S., Ta M. (2010). Increased proliferation and analysis of differential gene expression in human Wharton's jellyderived mesenchymal stromal cells under hypoxia. Int J Biol Sci, 6, 499-512. https://doi.org/10.7150/ijbs.6.499

25. Paiva K.B., Granjeiro J.M. (2014). Bone tissue remodeling and development: focus on matrix metalloproteinase functions. Arch Biochem Biophys, 561, 74-87. https://doi.org/10.1016/j.abb.2014.07.034

26. Pilmane M., Luts A., Sundler F. (1995). Changes in neuroendocrine elements in bronchial mucosa in chronic lung disease in adults. Thorax, 50, 551-554. https://doi.org/10.1136/thx.50.5.551

27. Ratajczak M.Z., Kim C., Ratajczak J., Janowska-Wieczorek A. (2013). Innate immunity as orchestrator of bone marrow homing for hematopoietic stem/ progenitor cells. Adv Exp Med Biol, 735, 219-232. https://doi.org/10.1007/978-1-4614-4118-2_15

28. Scalea J.R., Tomita Y., Lindholm C.R., Burlingham W. (2016). Transplantation Tolerance Induction: Cell Therapies and Their Mechanisms. Front Immunol, 7, 87. https://doi.org/10.3389/fimmu.2016.00087

29. Shi Q., VandeBerg J.L. (2015). Experimental approaches to derive CD34+ progenitors from human and nonhuman primate embryonic stem cells. Am J Stem Cells, 4, 32-37. 
30. Stefanini M., De Martino C., Zamboni L. (1967). Fixation of ejaculated spermatozoa for electron microscopy. Nature, 216, 173-174.

https://doi.org/10.1038/216173a0

31. Subramanian A., Fong C.Y., Biswas A., Bongso A. (2015). Comparative Characterization of Cells from the Various Compartments of the Human Umbilical Cord Shows that the Wharton's Jelly Compartment Provides the Best Source of Clinically Utilizable Mesenchymal Stem Cells. PLoS One, 10, e0127992. https://doi.org/10.1371/journal.pone.0127992

32. Sung D.K., Chang Y.S., Sung S.I., Yoo H.S., Ahn S.Y., Park W.S. (2016). Antibacterial effect of mesenchymal stem cells against Escherichia coli is mediated by secretion of beta-defensin-2 via toll-like receptor 4 signalling. Cell Microbiol, 18, 424-436. https://doi.org/10.1111/cmi.12522

33. Ullah I., Subbarao R.B., Rho G.J. (2015). Human mesenchymal stem cells - current trends and future prospective. Biosci Rep, 35pii, e00191. https://doi.org/10.1042/BSR20150025

34. Xie L., Zeng X., Hu J., Chen Q. (2015). Characterization of Nestin, a Selective Marker for Bone Marrow Derived Mesenchymal Stem Cells. Stem Cells Int, 2015, 762098. https://doi.org/10.1155/2015/762098

35. Wang H.S., Hung S.C., Peng S.T., Huang C.C., Wei H.M., Guo Y.J., Fu Y.S., Lai M.C., Chen C.C. (2004). Mesenchymal stem cells in the Wharton's jelly of the human umbilical cord. Stem Cells, 22, 1330-1337. https://doi.org/10.1634/stemcells.2004-0013

36. Zhou C., Yang B., Tian Y. et al. (2011). Immunomodulatory effect of human umbilical cord Wharton's jelly-derived mesenchymal stem cells on lymphocytes. Cell Immunol, 272, 33-38. https://doi.org/10.1016/j.cellimm.2011.09.010

37. Zhuang H., Zhang R., Zhang S., Shu Q., Zhang D., Xu G. (2015). Altered expression of microRNAs in the neuronal differentiation of human Wharton's Jelly mesenchymal stem cells. Neurosci Lett, 600, 69-74.

https://doi.org/10.1016/j.neulet.2015.05.061

\section{Address for correspondence:}

Elga Sidhom

Address: Kronvalda bulv. 9, Riga, LV-1010, Latvia

Phone number: +37129336041

E-mail address: Elga.Sidhoma@rsu.lv 